\title{
The Role of Endogenous Ethylene in Carbohydrate Metabolism of Medicago sativa L. Somatic Embryos in Relation to Their Regenerative Ability
}

\author{
Ewa Kępczyńska · Sylwia Zielińska
}

Received: 13 December 2011/Accepted: 16 May 2012/Published online: 28 June 2012

(C) The Author(s) 2012. This article is published with open access at Springerlink.com

\begin{abstract}
Effects of the ethylene biosynthesis inhibitors salicylic acid (SA) and aminoethoxyvinylglycine (AVG) on germination of Medicago sativa $\mathrm{L}$. somatic embryos and their conversion to seedlings in relation to carbohydrate content and $\alpha$-amylase activity were studied. Both SA, an inhibitor of ACC oxidase, and AVG, an inhibitor of ACC synthase, when present in the regeneration medium $(0.1$ and $1 \mu \mathrm{M}$ ) were found to drastically reduce the embryo germination rate. In addition, SA and AVG were found to almost completely or completely, respectively, arrest the process of embryo conversion to seedlings. The inhibitory effects of SA and AVG on germination and conversion may indicate that the processes required endogenous ethylene. AVG and SA clearly slowed down starch disappearance during the 48-h imbibition in the regeneration medium prior to radicle elongation, which was correlated with inhibition of the activity of $\alpha$-amylase, an enzyme responsible for starch hydrolysis. It is probable that ethylene may activate $\alpha$-amylase in the germinating alfalfa somatic embryos. In contrast, the disappearance of soluble sugars in the embryos in the presence of the inhibitors tested was accelerated. The disappearance of soluble sugars (to null or almost null) in embryos was faster in the presence of SA in the regeneration medium after 24 and $48 \mathrm{~h}$ compared to the disappearance rate with AVG present in the medium. Only glucose was present after a 48 -h incubation in the regeneration medium in the presence of the two ethylene biosynthesis inhibitors, in contrast to the control embryos in which glucose was not detected.
\end{abstract}

E. Kępczyńska $(\bowtie) \cdot$ S. Zielińska

Department of Plant Biotechnology, Faculty of Biology, University of Szczecin, Wạska 13, 71-415 Szczecin, Poland e-mail: ekepcz@univ.szczecin.pl
Keywords Alfalfa $\alpha$-amylase $\cdot$ Ethylene biosynthesis inhibitors - Medicago sativa L. - Soluble carbohydrates . Somatic embryo germination and conversion $\cdot$ Starch

\section{Introduction}

Somatic embryogenesis (SE) is a cloning technique based on tissue culture and can produce an unlimited number of embryos. To date, such vegetative propagation techniques are regarded as the lowest-cost methods for producing uniform, identical plants, particularly of those species that are difficult to propagate in a natural way (with seeds) or in other conventional manners. Although the process has been applied to numerous valuable plants, including Medicago sativa L., there are still several problems that restrict its wide use, including (1) asynchronous development of somatic embryos and (2) low germination and conversion rates of somatic embryos to normal plantlets. The major factor affecting seedling vigor of $M$. sativa $\mathrm{L}$. is the lack of sufficient and proper storage reserves in somatic embryos (Lai and others 1995). Unlike seeds, the alfalfa somatic embryos lack galactomannans because they have no endosperm (McCleary and Matheson 1976) and contain relatively low levels of storage proteins (Krochko and others 1992). Instead of galactomannan, they contain starch and soluble carbohydrates (Lai and McKersie 1994; Horbowicz and others 1995). During imbibition, alfalfa somatic embryos were observed to rapidly lose starch and soluble sugars; as early as the first day of germination, $50 \%$ of the contents of the above-mentioned storage carbohydrates was hydrolyzed (Lai and others 1995). A positive correlation between increased conversion rate and starch levels was observed when alfalfa somatic embryos were maturated on a medium supplemented with abscisic 
acid (ABA) (Fujii and others 1990). On the other hand, Lai and McKersie (1994) suggested that the quality of mature somatic embryos, determined by the rate of seedling development (conversion), was not correlated with starch content. However, the observed improvement in germination and conversion of alfalfa somatic embryos by gibberellic acid $\left(\mathrm{GA}_{3}\right)$, a known seed germination stimulator that accelerates starch hydrolysis through $\alpha$-amylase activity, is evidence that starch reserves are responsible for embryo regeneration (Kępczyńska and Zielińska 2006). Moreover, residual amounts of ABA present in somatic embryos after they have been treated with $20 \mu \mathrm{M}$ ABA during the maturation phase can affect the activity of the enzyme because retardation of starch hydrolysis in the presence of $\mathrm{ABA}$ in the germination medium was correlated with ABA's inhibitory effect on $\alpha$-amylase activity (Kępczyńska and Zielińska 2006). There is a lack information about the role of ethylene in embryo germination and conversion, although the part played by ethylene in somatic embryogenesis (SE) of $M$. sativa $\mathrm{L}$. has already been widely documented in different phases and regeneration protocols (Meijer and Brown 1988; Meijer 1989; Kępczyński and others 1992; Huang and others 2001; Kępczyński and others 2009a, b; Kępczyńska and Zielińska 2011). It has been unequivocally demonstrated that endogenous ethylene is necessary during differentiation (Meijer and Brown 1988; Meijer 1989; Kępczyński and others 1992) and also in proliferation of alfalfa somatic embryos (Kępczyńska and others 2009a, b). Moreover, disturbance of ethylene biosynthesis and action during these phases of SE adversely affects the vigor of the somatic embryos obtained (Kępczyńska and Zielińska 2011).

In this study we addressed the question of whether endogenous ethylene, a known stimulator of seed germination (Kępczyński and Kępczyńska 1997; Matilla and others 2005; Matilla and Matilla-Vázquez 2008) and seedling growth (Kępczyński and Kępczyńska 1997; Locke and others 2000), participates in the regulation of M. sativa somatic embryo germination and conversion (regeneration), and whether it affects soluble sugars, starch accumulation, and the activity of $\alpha$-amylase, an enzyme responsible for starch digestion. Therefore, during regeneration of embryos in the MS medium we used nonspecific ethylene biosynthesis inhibitors of ACC oxidase and ACC synthase: salicylic acid (SA) and aminoethoxyvinylglycine (AVG). The objectives of the current study were to determine how modification of ethylene biosynthesis could affect embryo germination and conversion, and whether there was a relationship between these processes and carbohydrate contents and $\alpha$-amylase activity during embryo imbibition prior to the start of germination (before root elongation).

\section{Materials and Methods}

\section{Plant Material}

Mother plants of $M$. sativa L. cv. Rangelander were grown in a growth chamber at $23 \pm 2{ }^{\circ} \mathrm{C}$ and $80 \%$ humidity at a $16-\mathrm{h}$ photoperiod (approximately $120 \mu \mathrm{mol} \mathrm{m} \mathrm{m}^{-2} \mathrm{~s}^{-1}$ PPFD). Petioles from the second to the fourth nodes from the top of 2-3-week-old plants were excised and served as a source of initial explants. They were surface-disinfected sequentially in $75 \%$ ethanol for $30 \mathrm{~s}$ and in $5 \%$ sodium hypochlorite for $4 \mathrm{~min}$, and then rinsed three times with sterile water and cut into $1.0-\mathrm{cm}$ pieces.

\section{Regeneration Protocol}

For callus induction, initial petiole explants were cultured for 14 days in $340-\mathrm{mL}$ jars on $40 \mathrm{~mL}$ medium of Schenk and Hildebrandt (1972) with some modifications (McKersie and others 1989). The medium contained $4.5 \mu \mathrm{M}$ 2,4-D, $0.9 \mu \mathrm{M}$ kinetin, $4.35 \mathrm{mg} \mathrm{L}^{-1} \mathrm{~K}_{2} \mathrm{SO}_{4}, 288 \mathrm{mg} \mathrm{L}^{-1}$ proline, $53 \mathrm{mg} \mathrm{L}^{-1}$ thioproline, and $200 \mathrm{mg} \mathrm{L}^{-1}$ myoinositol (Sigma-Aldrich, St. Louis, MO, USA) and was solidified with $9 \mathrm{~g} \mathrm{~L}^{-1}$ LAB-AGAR ${ }^{\mathrm{TM}}$ (BIOCORP, Warsaw, Poland). The cultures were incubated at $25 \pm 1{ }^{\circ} \mathrm{C}$ at a 16-h photoperiod (50 $\mu \mathrm{mol} \mathrm{m}{ }^{-2} \mathrm{~s}^{-1}$ PPFD). Suspension cultures were initiated from the proliferated calluses (about $1 \mathrm{~g}$ fresh weight [FW]) by subculturing in $100-\mathrm{mL}$ Erlenmeyer flasks on $40 \mathrm{~mL}$ liquid $\mathrm{B}_{5} \mathrm{~g}$, which is a standard $\mathrm{B}_{5}$ medium (Gamborg and others 1968) modified to contain $4.5 \mu \mathrm{M}$ 2,4-D and $0.5 \mu \mathrm{M}$ NAA (Sigma-Aldrich). The culture was kept for 7 days at $25^{\circ} \mathrm{C}, 50 \mu \mathrm{mol} \mathrm{m} \mathrm{m}^{-2} \mathrm{~s}^{-1}$ PPFD, and a 16-h photoperiod in a refrigerated incubator shaker at $120 \mathrm{rpm}$ (Innova 4340, New Brunswick Scientific, New Brunswick, NJ, USA). Small embryogenic cell aggregates were isolated by sieving the cell suspension through 500- and 200- $\mu$ m nylon meshes (Nitex, Sefar AG, Switzerland). For embryo development, the 200-500- $\mu \mathrm{m}$ fraction was spread $(0.5 \mathrm{~mL})$ on a $200-\mu \mathrm{m}$ nylon mesh over hormone-free BOi2Y medium (Bingham and others 1975) containing $0.15 \mathrm{M}$ sucrose $(10 \mathrm{~mL}$ medium in $60-\mathrm{mm}$ Petri dishes). Two weeks later (38 days after induction), somatic embryos were transferred to the BOi2Y medium with $20 \mu \mathrm{M}$ ABA (Sigma-Aldrich) (maturation medium). When the somatic embryos at the cotyledonary stage became yellow, they were slow-dried by exposure, over 12 days, to a series of environments of progressively lower relative humidity (RH). These atmospheres were generated in desiccators containing saturated salt solutions: $\mathrm{NaCl}$ $(\mathrm{RH}=78 \%)$ for $24 \mathrm{~h}, \mathrm{NH}_{4} \mathrm{NO}_{3}(\mathrm{RH}=63 \%)$ for $48 \mathrm{~h}$, $\mathrm{Ca}\left(\mathrm{NO}_{3}\right)_{2}(\mathrm{RH}=51 \%)$ for $48 \mathrm{~h}$, and $\mathrm{K}_{2} \mathrm{CO}_{3}(\mathrm{RH}=$ $43 \%)$ for 7 days. 
Germination and Conversion of Somatic Embryos

Twenty randomly selected dried embryos at the cotyledonary stage per replicate were germinated on the MS medium (Murashige and Skoog 1962) with or without hormones and their inhibitors. After 7 days on the MS medium, the somatic embryos, with visible radicles longer than $2 \mathrm{~mm}$, were scored as germinated, and after 2 weeks the conversion rate $(\%)$ was determined. The plant conversion criterion was the presence of roots and the presence of at least one trifoliate leaf.

Treatments Involving Inhibitors of Ethylene Biosynthesis

To perform the treatments, AVG and SA (Sigma-Aldrich), both ethylene biosynthesis inhibitors, were added separately after filtered sterilization to the autoclaved MS medium at the germination and conversion phases. The inhibitors were used at concentrations of 0.1 and $1 \mu \mathrm{M}$ in solutions of pH 5.8.

\section{Starch Extraction and Analysis}

The starch content and $\alpha$-amylase activity were determined in the cotyledonary somatic embryos after slow desiccation and after 24 and $48 \mathrm{~h}$ of germination on the MS medium with or without ethylene biosynthesis inhibitors. The somatic embryos examined after $24 \mathrm{~h}$ did not show germination, whereas after $48 \mathrm{~h}$ some of them showed the beginning of germination or root elongation (roots shorter than $2 \mathrm{~mm}$ ).

Starch was analyzed using the enzyme digestion method (according to a Sigma-Aldrich the technical bulletin was attached to the product, which code was SA-20 in Sigma-Aldrich) and a kit containing two reagents (Product Code SA-20). Samples of somatic embryos $(0.1 \mathrm{~g})$ were ground with a mortar and pestle and transferred to a 100 -mL Erlenmeyer flask. While stirring, $25 \mathrm{~mL}$ deionized water was added to the sample and its $\mathrm{pH}$ was adjusted to 5-7, whereupon the sample was boiled, with gentle stirring, for $3 \mathrm{~min}$. After boiling, the samples were autoclaved at $135{ }^{\circ} \mathrm{C}$ for $1 \mathrm{~h}$. After removal from the autoclave, the sample volume was brought to $100 \mathrm{~mL}$ by adding deionized water to the solution. The solutions were dosed to marked test tubes to $1 \mathrm{~mL}$ and mixed with $1 \mathrm{~mL}$ starch assay reagent (amyloglucosidase from Aspergillus niger at a buffer concentration of $50 \mathrm{U} \mathrm{mL}^{-1}$ ). At the same time, a sample blank ( $1 \mathrm{~mL}$ sample and $1 \mathrm{~mL}$ deionized water), a starch assay reagent blank $(1 \mathrm{~mL}$ reagent and $1 \mathrm{~mL}$ deionized water), and a glucose assay reagent blank $(2 \mathrm{~mL}$ reagent) were prepared. All the tubes were mixed and incubated at $60{ }^{\circ} \mathrm{C}$ for $15 \mathrm{~min}$ in a shaking water bath.
After incubation, the tubes were removed and cooled to room temperature. Then, $200-\mu \mathrm{L}$ portions of the solutions were pipetted to new tubes and mixed with $1 \mathrm{~mL}$ of the second reagent—a glucose assay reagent containing $1.5 \mathrm{mM} \mathrm{NAD}$, $1 \mathrm{mM}$ ATP, $1 \mathrm{U} \mathrm{mL}^{-1}$ hexokinase, and $1 \mathrm{U} \mathrm{mL}^{-1}$ glucose6-phosphate dehydrogenase with $0.05 \%$ sodium azide as a preservative. The tubes were mixed and incubated at room temperature for $15 \mathrm{~min}$. The absorbance of the solutions in the tubes was measured at $340 \mathrm{~nm}$ with water as reference. The starch content was calculated according to the SigmaAldrich specification.

Extraction and $\alpha$-Amylase Assay

The activity of $\alpha$-amylase was measured as described by Black and others (1996), with some modifications. Dry somatic embryos and those kept for 24 or $48 \mathrm{~h}$ on the germinating medium ( $0.1 \mathrm{~g}$ FW samples) were homogenized in $3 \mathrm{~mL}$ buffer containing $20 \mathrm{mM}$ Trizma maleate and $1 \mathrm{mM} \mathrm{CaCl} 2$ at $\mathrm{pH}$ 6.2. The homogenates were centrifuged at 12,000 rpm for $5 \mathrm{~min}$. Then, the reaction mixtures, consisting of $1.2 \mathrm{~mL}$ buffer and $1.2 \mathrm{~mL} \alpha$-amylase extract from the sample homogenates, were prepared. The sample blank was $2.4 \mathrm{~mL}$ buffer. These solutions were preincubated at $37^{\circ} \mathrm{C}$ for $2 \mathrm{~min}$ in a shaking water bath. Subsequently, Phadebas (Pharmacia Diagnostics, Uppsala, Sweden), a substrate for $\alpha$-amylase, that is, a colored insoluble starch in a concentration of $25 \mathrm{mg} \mathrm{mL}^{-1}$, was added $(0.6 \mathrm{~mL})$. The samples were again incubated at $37{ }^{\circ} \mathrm{C}$ for $30 \mathrm{~min}$ in a shaking water bath. After incubation, $0.6 \mathrm{~mL} 0.5 \mathrm{M} \mathrm{NaOH}$ was added to stop the reaction catalyzed by $\alpha$-amylase. All the samples were drained to clean tubes and centrifuged at 2,000 rpm for $3 \mathrm{~min}$. Then, the absorbance of the supernatant was measured at $620 \mathrm{~nm}$ against a sample blank. A calibration curve using barley malt $\alpha$-amylase (Pharmacia Diagnostics) was prepared, from which units of the extracted enzyme were calculated and expressed in nanokatals (nkat)/embryo.

\section{Extraction and Determination of Soluble Carbohydrate Content (HPLC Analysis)}

Soluble carbohydrates were extracted from the somatic embryos as described by Wolkers and others (1999): $10 \mathrm{mg}$ of dry cotyledonary somatic embryos that were incubated in the presence of AVG and SA during germination were homogenized in a mortar with $1 \mathrm{ml} 80 \%$ methanol. The homogenates, transferred to Eppendorf tubes, were incubated in a heater at $76{ }^{\circ} \mathrm{C}$ for $15 \mathrm{~min}$. After incubation, the samples were centrifuged at $14,000 \mathrm{rpm}$ for $5 \mathrm{~min}$, and then methanol was gradually evaporated from the supernatants in clean tubes in Speedvac Eppendorf $\left(45^{\circ} \mathrm{C}\right.$ for $2 \mathrm{~h})$. The residue in the tubes was dissolved in the mixture 
of $70 \%$ acetonitrile (J.T. Baker, Mallinckrodt Baker Inc.) $(\mathrm{ACN}, 0.6 \mathrm{~mL})$ and ultrapure water $(0.2 \mathrm{~mL})$. After filtration, the samples were poured into new vessels with rubber stoppers and were analyzed in the Agilent 1100 HPLC system, equipped with an isocratic pump, RID detector, and Zorbax carbohydrate column $(5 \mu \mathrm{m}$, $250 \times 4.6 \mathrm{~mm}$ ), at $40{ }^{\circ} \mathrm{C}$ at a flow rate of $70 \% \mathrm{ACN} / \mathrm{H}_{2} \mathrm{O}$ $1.5 \mathrm{~mL} \mathrm{~min}^{-1}$ for $22 \mathrm{~min}$. The soluble sugars glucose, sucrose, raffinose, and stachyose were detected and identified using a calibration curve method with original external standards from Sigma-Aldrich. The quantities of glucose, sucrose, raffinose, and stachyose were calculated using ChemStation LC Rev. A.10.01 (Agilent Technologies, Palo Alto, CA, USA).

\section{Statistical Treatment}

Each experiment was run in five replicates. The statistical treatment of the data involved the analysis of variance (ANOVA) using Statistica for Windows v6.0 software (Statsoft Inc., Tulsa, OK, USA). Differences between means were considered to be significant at $p<0.05$, as indicated by Duncan's multiple-range test.

\section{Results}

Effects of Ethylene Biosynthesis Inhibitors SA and AVG on the Germination and Conversion of Somatic Embryos

Addition of SA, an inhibitor of ACC oxidase activity, to the germination MS medium at concentrations of 0.1 and $1 \mu \mathrm{M}$ had an inhibitory effect on embryo germination.

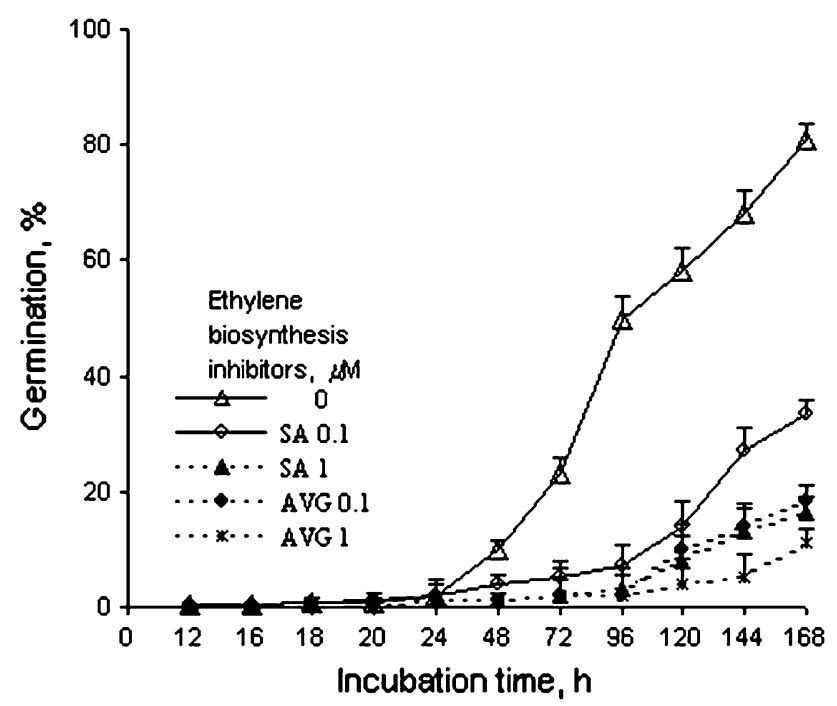

Fig. 1 Effects of SA and AVG on the dynamics of $M$. sativa $\mathrm{L}$. somatic embryo germination over 7 days
After $168 \mathrm{~h}$ (7 days), about 60 and $80 \%$ germination reduction rates were observed, respectively (Fig. 1). The presence of AVG, another ethylene biosynthesis inhibitor that depresses ACC synthase activity, in the above-mentioned medium inhibited the germination as well. AVG concentrations of 0.1 and $1 \mu \mathrm{M}$ resulted in about 77 and $87 \%$ inhibition, respectively, compared to the control.

The presence of SA in the regeneration medium resulted in a sharp drop in the conversion ability of the germinated embryos between days 7 and 14 (Table 1). When the inhibitor was applied at concentrations of 0.1 and $1 \mu \mathrm{M}$, it caused nearly 85 and $90 \%$ conversion reductions, respectively, compared to the control. A still larger inhibitory effect on the process was observed when AVG was applied at concentrations of 0.1 and $1 \mu \mathrm{M}$; the effect was a complete inhibition of conversion in the germinated embryos.

Effects of SA and AVG on Starch Content and $\alpha$ Amylase Activity in Imbibed Somatic Embryos

Because starch is a major carbohydrate storage compound in alfalfa somatic embryos, subsequent experiments were aimed at finding out if inhibition of ethylene biosynthesis during imbibition, the first phase of the germination process, would affect starch hydrolysis (Table 2). The starch level in dry somatic embryos was nearly 14 times higher $(2,230 \mu \mathrm{g} /$ embryo $)$ than that in embryos imbibed for $24 \mathrm{~h}$ on the germination MS medium (160 $\mu \mathrm{g}$ /embryo). At this time, the embryonic root apex was enlarged. After $48 \mathrm{~h}$, when the embryos (10\%) were beginning to show the start of root elongation (below $2 \mathrm{~mm}$ ) (Fig. 1), starch was present in the embryos at concentrations as low as $51 \mu \mathrm{g} /$ embryo, with the concentrations about three times lower than those in 1-day imbibed embryos (Table 2). Thus, during the first period of incubation on the germination medium (48 h), starch was observed to disappear very quickly. Addition of $\mathrm{SA}$ to the germination medium at $0.1-\mu \mathrm{M}$ concentration had no effect on the starch hydrolysis rate after $24 \mathrm{~h}$ compared to control. However, in the presence of $1-\mu \mathrm{M}$ concentration, SA slowed down the disappearance of starch in the embryos after $24 \mathrm{~h}$ : starch

Table 1 Effects of SA and AVG on conversion (after 14 days) of somatic embryos of M. sativa $\mathrm{L}$

\begin{tabular}{|c|c|c|}
\hline \multirow{2}{*}{$\begin{array}{l}\text { Ethylene biosynthesis } \\
\text { inhibitors }(\mu \mathrm{M})\end{array}$} & \multicolumn{2}{|c|}{ Conversion $(\% \pm \mathrm{SE})$} \\
\hline & SA & AVG \\
\hline 0 & \multicolumn{2}{|c|}{$73.3 \pm 1.5 \mathrm{a}$} \\
\hline 0.1 & $11.1 \pm 0.5 b$ & $0.0 \pm 0.3 \mathrm{~d}$ \\
\hline 1 & $8.3 \pm 0.8 c$ & $0.0 \pm 0.2 \mathrm{c}$ \\
\hline
\end{tabular}

Data are the means of five replicates. Means with common letters are not significantly different at $p<0.05$, according to Duncan's multiple-range test 
Table 2 Content of starch and $\alpha$-amylase activity after 24 and $48 \mathrm{~h}$ on regeneration medium of alfalfa somatic embryos in the presence of AVG and SA

\begin{tabular}{|c|c|c|c|c|c|c|}
\hline \multirow{2}{*}{$\begin{array}{l}\text { Ethylene biosynthesis } \\
\text { inhibitors }(\mu \mathrm{M})\end{array}$} & \multicolumn{3}{|c|}{ Starch content ( $\mu \mathrm{g} / \mathrm{embryo})$} & \multicolumn{3}{|c|}{$\alpha$-amylase activity (nkat/embryo) } \\
\hline & $\begin{array}{l}\text { After } \\
\text { desiccation }\end{array}$ & $\begin{array}{l}\text { After } 24 \mathrm{~h} \\
\text { of imbibition }\end{array}$ & $\begin{array}{l}\text { After } 48 \mathrm{~h} \\
\text { of imbibition }\end{array}$ & After desiccation & $\begin{array}{l}\text { After } 24 \mathrm{~h} \\
\text { of imbibition }\end{array}$ & $\begin{array}{l}\text { After } 48 \mathrm{~h} \\
\text { of imbibition }\end{array}$ \\
\hline 0 & $2230 a$ & $160 \mathrm{c}$ & $51 \mathrm{~d}$ & $0.020 \mathrm{~d}$ & $1.054 \mathrm{a}$ & $0.570 \mathrm{~b}$ \\
\hline SA 0.1 & & $158 \mathrm{c}$ & $142 \mathrm{c}$ & & $0.055 \mathrm{c}$ & $0.059 \mathrm{c}$ \\
\hline SA 1 & & $650 \mathrm{~b}$ & $650 \mathrm{~b}$ & & $0.008 \mathrm{e}$ & $0.006 \mathrm{e}$ \\
\hline AVG 0.1 & & $216 \mathrm{c}$ & $193 c$ & & $0.055 \mathrm{c}$ & $0.029 \mathrm{~d}$ \\
\hline AVG 1 & & $610 \mathrm{~b}$ & $550 \mathrm{~b}$ & & $0.006 \mathrm{e}$ & $0.003 \mathrm{f}$ \\
\hline
\end{tabular}

Data are the means of five replicates. Means with common letters are not significantly different at $p<0.05$, according to Duncan's multiplerange test

Table 3 Carbohydrate composition of dry and 24- and 48-h imbibed somatic embryos

\begin{tabular}{lcll}
\hline $\begin{array}{l}\text { Carbohydrate } \\
\text { content }(\%)^{\mathrm{a}}\end{array}$ & $\begin{array}{l}\text { Dry } \\
\text { embryos }\end{array}$ & $\begin{array}{l}\text { After } 24 \mathrm{~h} \\
\text { of imbibition }\end{array}$ & $\begin{array}{l}\text { After } 48 \mathrm{~h} \\
\text { of imbibition }\end{array}$ \\
\hline Starch & $94.67 \mathrm{a}$ & $6.79 \mathrm{~b}$ & $2.17 \mathrm{c}$ \\
Glucose & $0.2 \mathrm{~h}$ & $0.05 \mathrm{i}$ & $0 \mathrm{i}$ \\
Sucrose & $1.24 \mathrm{e}$ & $0.38 \mathrm{~g}$ & $0.15 \mathrm{~h}$ \\
Raffinose & $1.72 \mathrm{~d}$ & $0.78 \mathrm{f}$ & $0.45 \mathrm{~g}$ \\
Stachyose & $2.17 \mathrm{c}$ & $0.21 \mathrm{~h}$ & $0.11 \mathrm{~h}$ \\
\hline
\end{tabular}

Data are the means of five replicates. Means with common letters are not significantly different at $p<0.05$, according to Duncan's multiple-range test

a $100 \%$ was the amount of total carbohydrates in dry embryos

hydrolysis was about four times slower than in the control. A similar effect was observed when AVG was added to the germination medium at $0.1-$ and $1-\mu \mathrm{M}$ concentrations.

Parallel to starch content assays, the $\alpha$-amylase activity in the embryos mentioned above was analyzed (Table 2). The enzyme activity in the embryos after 24-h imbibition on the MS medium was at its highest and was about 53 times higher than that in dry embryos. When embryo roots started to elongate (below $2 \mathrm{~mm}$ ) between 24 and $48 \mathrm{~h}$ of incubation on the germination medium (Fig. 1), the enzyme activity clearly decreased, although it was 29 times higher than that in dry embryos. The two ethylene biosynthesis inhibitors, at concentrations of 0.1 and $1 \mu \mathrm{M}$, drastically inhibited the $\alpha$-amylase activity after 24 and $48 \mathrm{~h}$ of embryo incubation. The enzyme activity in the embryos germinated in the presence of 0.1 and $1 \mu \mathrm{M} \mathrm{SA}$ was about 20 and 130, which was 10 and 95 times lower after 24 and $48 \mathrm{~h}$, respectively, than in the embryos not treated with SA. AVG at 0.1 and $1 \mu \mathrm{M}$ evidently inhibited the $\alpha$-amylase activity as well; about 19 -fold and 190 -fold reductions in the activities of this enzyme were recorded after 24- and 48-h imbibition of the embryos, respectively. These results indicate that the observed inhibition of starch hydrolysis in the presence of ethylene biosynthesis inhibitors was correlated with inhibitory effects of these compounds on the activity of $\alpha$-amylase, the enzyme responsible for starch hydrolysis.

Changes in the Content of Soluble Carbohydrates

During Incubation on the MS Medium in the Absence and Presence of SA and AVG

Because alfalfa somatic embryos store soluble carbohydrates in addition to starch, we also examined changes in the concentration of soluble sugars during imbibition on the germination MS medium in the absence and presence of ethylene biosynthesis inhibitors SA and AVG (Tables 3, 4). In dry embryos, the content of total soluble sugars (5.3\% stachyose, raffinose, sucrose, and glucose) was about 17 times lower than the starch content. Stachyose and raffinose dominated among carbohydrates, accounting for 2.17 and $1.72 \%$ of total carbohydrates, respectively. The level of glucose, a monosaccharide, was the lowest: about $0.2 \%$ of total carbohydrates per embryo was recorded. The content of sucrose, a disaccharide, was about 4 times higher than that of glucose. During $24 \mathrm{~h}$ of imbibition on the germination MS medium, a very fast disappearance of carbohydrates was observed. Concentrations of starch and soluble sugars (glucose, sucrose, raffinose, and stachyose) decreased significantly compared to those in dry embryos. The highest degradation (14-fold reduction) was observed in starch, followed by stachyose (10-fold), glucose (4-fold), sucrose (3-fold), and raffinose (2-fold). Over the next $24 \mathrm{~h}$ of imbibition, a further reduction in the sugar contents was observed, with no glucose detected in the imbibed embryos after $48 \mathrm{~h}$. Sucrose and raffinose were disappearing at rates comparable to those observed in the embryos during the first $24 \mathrm{~h}$ of imbibition, but the disappearance rate was clearly diminished in stachyose.

In the embryos imbibed for 24 and $48 \mathrm{~h}$ in the presence of SA, applied at concentrations of 0.1 and $1 \mu \mathrm{M}$, no sucrose, raffinose, and stachyose were detected (Table 4). 
Table 4 Content ( $\mu$ g/embryo) of glucose, sucrose, raffinose, and stachyose after 24 and $48 \mathrm{~h}$ on regeneration medium of alfalfa somatic embryos in the presence of SA or AVG

\begin{tabular}{|c|c|c|c|c|c|}
\hline $\begin{array}{l}\text { Ethylene } \\
\text { biosynthesis } \\
\text { inhibitors }(\mu \mathrm{M})\end{array}$ & $\begin{array}{l}\text { After } \\
\text { desiccation }\end{array}$ & \multicolumn{2}{|c|}{$\begin{array}{l}\text { After } 24 \mathrm{~h} \\
\text { of imbibition }\end{array}$} & \multicolumn{2}{|c|}{$\begin{array}{l}\text { After } 48 \mathrm{~h} \\
\text { of imbibition }\end{array}$} \\
\hline \multicolumn{6}{|l|}{ Glucose } \\
\hline \multirow[t]{2}{*}{0} & \multirow[t]{2}{*}{$7.23 \mathrm{a}$} & $1.2 \mathrm{~b}$ & & \multicolumn{2}{|l|}{$0.00 \mathrm{~d}$} \\
\hline & & SA & AVG & SA & AVG \\
\hline 0.1 & - & $0.10 \mathrm{~d}$ & $0.89 \mathrm{c}$ & $0.10 \mathrm{~d}$ & $0.70 \mathrm{c}$ \\
\hline 1 & - & $0.23 \mathrm{~d}$ & $1.34 \mathrm{~b}$ & $0.08 \mathrm{~d}$ & $1.45 \mathrm{~b}$ \\
\hline \multicolumn{6}{|l|}{ Sucrose } \\
\hline \multirow[t]{2}{*}{0} & \multirow[t]{2}{*}{$29.3 \mathrm{a}$} & $9.03 b$ & & $3.5 \mathrm{c}$ & \\
\hline & & SA & AVG & SA & AVG \\
\hline 0.1 & - & $0.00 \mathrm{~d}$ & $0.00 \mathrm{~d}$ & $0.00 \mathrm{~d}$ & $0.00 \mathrm{~d}$ \\
\hline 1 & - & $0.00 \mathrm{~d}$ & $0.18 \mathrm{~d}$ & $0.00 \mathrm{~d}$ & $0.12 \mathrm{~d}$ \\
\hline \multicolumn{6}{|l|}{ Raffinose } \\
\hline \multirow[t]{2}{*}{0} & \multirow[t]{2}{*}{$40.7 \mathrm{a}$} & $18.4 \mathrm{~b}$ & & $10.5 \mathrm{c}$ & \\
\hline & & SA & AVG & SA & AVG \\
\hline 0.1 & - & $0.00 \mathrm{e}$ & $8.82 \mathrm{~d}$ & $0.00 \mathrm{e}$ & $6.72 \mathrm{~d}$ \\
\hline 1 & - & $0.12 \mathrm{e}$ & $7.31 \mathrm{~d}$ & $0.00 \mathrm{e}$ & $5.05 c$ \\
\hline \multicolumn{6}{|l|}{ Stachyose } \\
\hline \multirow[t]{2}{*}{0} & \multirow[t]{2}{*}{$51.3 \mathrm{a}$} & $4.9 \mathrm{~b}$ & & $2.57 \mathrm{c}$ & \\
\hline & & SA & AVG & SA & AVG \\
\hline 0.1 & - & $0.00 \mathrm{~d}$ & $0.00 \mathrm{~d}$ & $0.00 \mathrm{~d}$ & $0.00 \mathrm{~d}$ \\
\hline 1 & - & $0.00 \mathrm{~d}$ & $0.00 \mathrm{~d}$ & $0.00 \mathrm{~d}$ & $0.00 \mathrm{~d}$ \\
\hline
\end{tabular}

Data are the means of five replicates. Means with common letters are not significantly different at $p<0.05$, according to Duncan's multiple-range test

Under those conditions, only vestigial quantities of glucose were detected. The presence of AVG, another ethylene biosynthesis inhibitor, during imbibition sped up the disappearance of sucrose and raffinose as well, but the disappearance rate was not as drastic as that caused by SA. Those embryos imbibed for 24 and $48 \mathrm{~h}$ failed to show any trace of stachyose. In contrast to the control embryos, which contained no glucose after $48 \mathrm{~h}$, the somatic embryos exposed to AVG showed the presence of glucose at a nearly identical level as that in the control embryos after 24-h imbibition.

To summarize, SA and AVG accelerated the disappearance of soluble sugars except glucose (Table 4), in contrast to starch, the hydrolysis of which was retarded in the presence of these ethylene biosynthesis inhibitors (Table 2).

\section{Discussion}

Plant hormones, including ethylene, are extremely important for the regulation of seed germination and seedling growth (Esashi 1991; Kępczyński and Kępczyńska 1997; Matilla 2000; Kucera and others 2005; Bradford and Nonogaki 2007). There is a lack of information on the role of endogenous ethylene during germination of the embryo and its conversion to a seedling. Inhibition of germination of somatic embryos of M. sativa L. cv. Rangelander due to the presence of two nonspecific ethylene biosynthesis inhibitors SA and AVG suggests that the process requires ethylene biosynthesis. As demonstrated earlier, application of those inhibitors during the proliferation phase of somatic embryogenesis not only brings about a decline in ethylene production and embryogenic suspension proliferation, it also inhibits production of embryos and their development, and, moreover, results in a loss of ability of the cotyledonary embryos kept on the differentiation and maturation media to germinate and convert when kept on the regeneration medium (Kępczyńska and Zielińska 2011). Thus, the results obtained previously and those reported in this article clearly indicate that endogenous ethylene, dependent on ACO and ACS activities, is required for germination and conversion of the somatic embryos of $M$. sativa L. cv. Rangelander.

The role of ethylene in seed germination is still being debated. Studies involving ethylene biosynthesis inhibitors (AOA and AVG) suggest that in several species, ethylene promotes the germination of nondormant seeds, with the germination rate (radicle protrusion) related to the level of ethylene production (Kępczyński and Kępczyńska 1997; Matilla and Matilla-Vázquez 2008). The maximum ethylene production in these seeds is usually detected after germination has ended (radicle protrusion); small amounts of the gas are also produced prior to germination (imbibition) and immediately before protrusion (Kępczyński and others 2003; Matilla and Matilla-Vázquez 2008). In regard to the genes involved in ethylene synthesis, IglesiasFernández and Matilla (2010) showed the expression of SoACS7 (ACC synthase gene) in Sisymbrium officinale L. seeds just prior to radicle emergence, whereas SoACO2 (ACC oxidase gene) expression slowly increased as germination progressed. Still, little is known about the mechanism of ethylene's role in the germination of ethylene-dependent seeds. The primary involvement of ethylene may be in the promotion of radial cell expansion in the embryogenic axis, increased respiration, or induction of $\beta$-1,3-glucanase responsible for endosperm rupture and radicle protrusion (Bradford and Nonogaki 2007; Matilla and Matilla-Vázquez 2008). Thus, the results obtained from this study indicate the importance of ethylene biosynthesis also in the germination of $M$. sativa $\mathrm{L}$. somatic embryos. The alfalfa somatic embryos are structurally different from seeds lacking both a coat and an endosperm, so they were not able to regulate water imbibition and gas exchange. Moreover, due to the lack of endosperm, they 
cannot store galactomannans, the major storage carbohydrate in seeds (McCleary and Matheson 1976). Instead of galactomannans, starch is the major reserve accumulated in the somatic embryos during differentiation and maturation in the presence of sucrose in the medium (Horbowicz and others 1995; Lai and others 1995), although other carbohydrates were present in mature embryos as well. The somatic embryos reported in this study had developed completely in a sucrose-rich $(30 \mathrm{~g} / \mathrm{L})$ medium, and the total content of soluble carbohydrates (stachyose, raffinose, sucrose, and glucose, $128.5 \mu \mathrm{g} /$ dry embryo) was nearly 17 times lower than the starch content $(2,230 \mu \mathrm{g} / \mathrm{dry}$ embryo). Similar results were reported for somatic embryos of avocado (Sanchez-Romero and others 2002) and Acca sellowiana (Pescador and others 2008). Starch, as the major carbohydrate storage compound in the alfalfa somatic embryos, was observed to rapidly disappear; after $24 \mathrm{~h}$ on the MS germination medium, more than $95 \%$ of the starch stored by dry embryos was hydrolyzed. Due to the lack of a coat and endosperm, dried embryos were rapidly rehydrated, which accelerated hydrolysis of stored reserves. Although somatic embryos of $M$. sativa do not have an endosperm like seeds in which $\alpha$-amylase synthesis occurs, they are able to produce $\alpha$-amylase (Kępczyńska and Zielińska 2006), the enzyme responsible for starch degradation during germination of alfalfa seeds (Kohno and Nanmori 1991). In the absence of aleurone tissue and endosperm in the somatic embryos of monocot bamboo, the scutellum plays a substitute role in amylase accumulation and acts as a starch deposition site (Godbole and others 2004). The inhibitory effect of ethylene biosynthesis inhibitors present in the germination medium on $\alpha$-amylase activity in embryos after 24 and $48 \mathrm{~h}$ on the MS medium and the inhibition of starch hydrolysis suggest that endogenous ethylene participates in the regulation of the enzyme's activity. A similar inhibition of $\alpha$-amylase activity accompanied by slowed-down starch hydrolysis by acetylsalicylic acid, an ethylene biosynthesis inhibitor, was observed in postharvest kiwifruit (Zhang and others 2004). Application of ethylene induced amylase activity and accelerated starch hydrolysis in these fruits. Application of 2,5-norbornadiene (NBD), an ethylene action inhibitor, resulted in the inhibition of $\alpha$-amylase activity after $20 \mathrm{~h}$ of imbibition of Amaranthus caudatus cv. atropurpureus seeds, with exogenous ethylene increasing the activity of the enzyme (Białecka and Kępczyński 2003). According to Jones (1968), ethylene can increase or decrease the quantity of $\alpha$-amylase in two ways: by affecting the synthesis of the enzyme and by influencing the $\alpha$-amylase release.

In addition to starch, the alfalfa somatic embryos contained other storage materials: soluble carbohydrates (glucose, sucrose, and RFO family sugars raffinose and stachyose). The rate at which soluble carbohydrates were utilized was analyzed in germinating seeds of many plant species. Upon imbibition, RFOs disappear rapidly, almost completely, before radicle protrusion (Górecki and others 1997), but the mechanism of soluble carbohydrate breakdown is far from understood (Peterbauer and Richter 2001). $\alpha$-Galactosidases were responsible for oligosaccharide hydrolysis during germination in, for example, lettuce (Leung and Bewley 1981), tomato (Feurtado and others 2001), and seeds of different legumes: Lupinus luteus L. (Lahuta and others 2000), Phaseolus lunatus, Cajanus cajan, Sphenostylis sternocarpa, Canavalia ensiformis (Oboh and others 2000), and sunflower seeds (Kim and others 2003); however, in Arachis hypogea seeds, for example, both $\alpha$ - and $\beta$-galactosidases were involved (Bryant and others 2004). However, correlation between the RFO breakdown and $\alpha$-galactosidase activity was observed only in the seed endosperm, which contains both RFOs and galactomannan, but not in the embryo, which is devoid of the latter (Peterbauer and Richter 2001). Exogenous ethylene was found to increase the $\alpha$-galactosidase activity in the endosperm and the testa during galactomannan degradation, suggesting an inducing effect of the hormone on the hydrolyzing enzyme during 2-day imbibition (before radicle protrusion) of Sesbania virgata seeds (Tonini and others 2010). Moreover, Tonini and others (2010) observed that glucose and sucrose are reduced after day 4, which suggests that the seedlings start to consume sugars for growth at the same time as galactomannan products are exhausted. During imbibition for up to $20 \mathrm{~h}$ (40\% of radicle protrusion) of Amaranthus caudatus seeds, exogenous ethylene produced a decrease in the contents of RFO, galactinol, and myoinositol, and a simultaneous increase in the contents of glucose, fructose, galactose, maltose, and maltotriose (Białecka and Kępczyński 2007).

The somatic embryos of $M$. sativa $\mathrm{L}$. imbibed on the MS medium, showed that after 24 and $48 \mathrm{~h}$ (before radicle protrusion) there was a gradual reduction of RFO (raffinose and stachyose) as well, which could suggest the presence of $\alpha$-galactosidases. However, in contrast to the seeds mentioned above, a reduction in sucrose and glucose was also observed. Acceleration of the use of sucrose, raffinose, and stachyose in the imbibed alfalfa somatic embryos in the presence of $\mathrm{AVG}$ and $\mathrm{SA}$, the ethylene biosynthesis inhibitors, probably requires a reduced level of endogenous ethylene. The drastic reduction of the starch and RFO levels in the somatic embryos of $M$. sativa during imbibition (to $48 \mathrm{~h}$ ) may have limited the rate of some anabolic reactions, which could have slowed down radicle and hypocotyl elongation and leaf development. The embryos converted to seedlings (70\% conversion rate) after only 14 days, with the process drastically reduced or nonexistent in the presence of SA or AVG in the regeneration MS 
medium, respectively. The lack of glucose in the control embryos after 48-h imbibition and the presence of the monosaccharide in those embryos imbibed on the medium supplemented with ethylene inhibitors is very interesting and needs more attention in the future, particularly in view of the information that glucose plays vital roles in plant growth and development as both an energy source and a signaling molecule, which is further controlled by phytohormones (Leon and Sheen 2003). Li and others (2009) observed that low levels of exogenous glucose in the MS germination medium of tobacco seeds promote seedling development, but that higher levels retard the process (smaller leaves, shorter roots, reduced FW). Their preliminary results indicate also that ethylene action and glucose response antagonistically affect root elongation.

The results reported in this article suggest that for the first time, endogenous ethylene in the regeneration medium may be involved in regulation of $M$. sativa $\mathrm{L}$. embryo germination and conversion by controlling starch hydrolysis through the influence on $\alpha$-amylase activity and metabolism of soluble carbohydrates.

Open Access This article is distributed under the terms of the Creative Commons Attribution License which permits any use, distribution, and reproduction in any medium, provided the original author(s) and the source are credited.

\section{References}

Białecka B, Kępczyński J (2003) Regulation of $\alpha$-amylase activity in Amaranthus caudatus seeds by methyl jasmonate, gibberellin $\mathrm{A}_{3}$, benzyladenine and ethylene. Plant Growth Regul 39:51-56

Białecka B, Kępczyński J (2007) Changes in concentrations of soluble carbohydrates during germination of Amaranthus caudatus $\mathrm{L}$. seeds in relation to ethylene, gibberellin $\mathrm{A}_{3}$ and methyl jasmonate. Plant Growth Regul 51:21-31

Bingham ET, Hurley LV, Kaatz DM, Saunders JW (1975) Breeding alfalfa which regenerates from callus tissue in culture. Crop Sci 15:719-721

Black M, Corbineau F, Grzesik M, Guy P, Côme D (1996) Carbohydrate metabolism in the developing and maturing wheat embryo in relation to its desiccation tolerance. J Exp Bot 47:161-169

Bradford K, Nonogaki H (2007) Seed development, dormancy and germination. Blackwell, Oxford, pp 197-200

Bryant RJ, Rao DR, Ogutu S (2004) $\alpha$ - and $\beta$-galactosidase activities and oligosaccharide content in peanuts. Plant Foods Hum Nutr 58:213-223

Esashi Y (1991) Ethylene and seed germination. In: Mattoo AK, Suttle JC (eds) The plant hormone ethylene. CRC Press, Boca Raton, pp 134-157

Feurtado JA, Banik M, Bewley JD (2001) The cloning and characterization of $\alpha$-galactosidase present during and following germination of tomato (Lycopersicon esculentum Mill.) seed. J Exp Bot 52:1239-1249

Fujii JAA, Slade D, Olsen R, Ruzin SE, Redenbaugh K (1990) Alfalfa somatic embryo maturation and conversion to plants. Plant Sci 72:93-100
Gamborg O, Miller R, Ojima K (1968) Nutrient requirements of suspension cultures of soybean root cells. Exp Cell Res 50:151-158

Godbole S, Sood A, Sharma M, Nagar PK, Ahuja PS (2004) Starch deposition and amylase accumulation during somatic embryogenesis in bamboo (Dendrocalamus hamiltonii). J Plant Physiol 161:245-248

Górecki RJ, Piotrowicz-Cieślak AI, Lahuta LB, Obendorf RL (1997) Soluble carbohydrates in desiccation tolerance of yellow lupin seeds during maturation and germination. Seed Sci Res 7:107115

Horbowicz M, Obendorf RL, MeKersie BD, Viands DR (1995) Soluble saccharides and cyclitols in alfalfa (Medicago sativa $\mathrm{L}$.) somatic embryos, leaflets, and mature seeds. Plant Sci 109:191-198

Huang XL, Li XJ, Li Y, Huang LZ (2001) The effect of AOA on ethylene and polyamine metabolism during early phases of somatic embryogenesis in Medicago sativa. Physiol Plant 113:424-429

Iglesias-Fernández R, Matilla AJ (2010) Genes involved in ethylene and gibberellins metabolism are required for endosperm-limited germination of Sisymbrium officinale L. seeds. Planta 231:653664

Jones RL (1968) Ethylene enhanced release of $\alpha$-amylase from barley aleurone cells. Plant Physiol 43:442-444

Kępczyńska E, Zielińska S (2006) Regulation of Medicago sativa L. somatic embryos regeneration by gibberellin $\mathrm{A}_{3}$ and abscisic acid in relation to starch content and $\alpha$-amylase activity. Plant Growth Regul 49:209-217

Kępczyńska E, Zielińska S (2011) Disturbance of ethylene biosynthesis and perception during somatic embryogenesis in Medicago sativa L. reduces embryos' ability to regenerate. Acta Physiol Plant 33:1969-1980

Kępczyńska E, Ruduś I, Kępczyński J (2009a) Endogenous ethylene in indirect somatic embryogenesis of Medicago sativa L. Plant Growth Regul 59:63-73

Kępczyńska E, Ruduś I, Kępczyński J (2009b) Abscisic acid and methyl jasmonate as regulators of ethylene biosynthesis during somatic embryogenesis of Medicago sativa $\mathrm{L}$. Acta Physiol Plant $31: 1263-1270$

Kępczyński J, Kępczyńska E (1997) Ethylene in seed dormancy and germination. Physiol Plant 101:720-726

Kępczyński J, McKersie BD, Brown DCW (1992) Requirement of ethylene for growth of callus and somatic embryogenesis in Medicago sativa L. J Exp Bot 43:1199-1202

Kępczyński J, Bihun M, Kępczyńska E (2003) The release of secondary dormancy by ethylene in Amaranthus caudatus L. seeds. Seed Sci Res 13:69-74

Kim WD, Kaneko S, Park GG, Tanaka H, Kusakabe I, Kobayashi H (2003) Purification and characterization of $\alpha$-galactosidase from sunflower seeds. Biotechnol Lett 25:353-358

Kohno A, Nanmori T (1991) Changes in $\alpha$ - and $\beta$-amylase activities during germination of seeds of alfalfa (Medicago sativa L.). Plant Cell Physiol 32:459-466

Krochko JE, Pramanik SK, Bewley JD (1992) Contrasting storage protein synthesis and messenger RNA accumulation during development of zygotic and somatic embryos of alfalfa (Medicago sativa L.). Plant Physiol 99:46-53

Kucera B, Cohn MA, Leubner-Metzger L (2005) Plant hormone interactions during seed dormancy release and germination. Seed Sci Res 15:281-307

Lahuta LB, Górecki RJ, Michalczyk D, Piotrowicz-Cieślak AI (2000) Alpha-D-galactosidase activity in stored yellow lupin (Lupinus luteus L.) seeds. Electron J Polish Agric Univ 3(1). http://www. ejpau.media.pl/series/volume3/issue1/agronomy/art05.html 
Lai FM, McKersie BD (1994) Regulation of starch and protein accumulation in alfalfa (Medicago sativa L.) somatic embryos. Plant Sci 100:211-219

Lai FM, Lecouteux CG, McKersie BD (1995) Germination of alfalfa (Medicago sativa L.) seeds and desiccated somatic embryos. I. Mobilization of storage reserves. J Plant Physiol 145:507-513

Leon P, Sheen J (2003) Sugar and hormone connections. Trends Plant Sci 8:110-116

Leung DWM, Bewley JD (1981) Red-light- and gibberellic-acidenhanced $\alpha$-galactosidase activity in germinating lettuce seeds, cv. Grand Rapids. Control by the axis. Planta 152:436-441

Li A, Zhang Z, Wang XC, Huang R (2009) Ethylene response factor TERF1 enhances glucose sensitivity in tobacco through activating the expression of sugar-related genes. J Integr Plant Biol 51:184-193

Locke JM, Bryce JH, Morris PC (2000) Contrasting effects of ethylene perception and biosynthesis inhibitors on germination and seedling growth of barley (Hordeum vulgare L.). J Exp Bot 51:1843-1849

Matilla AJ (2000) Ethylene in seed formation and germination. Seed Sci Res 10:111-126

Matilla AJ, Matilla-Vázquez MA (2008) Involvement of ethylene in seed physiology. Plant Sci 175:87-97

Matilla AJ, Gallardo M, Puga-Hermida MI (2005) Structural, physiological and molecular aspects of heterogeneity in seeds: a review. Seed Sci Res 15:63-76

McCleary BV, Matheson NK (1976) Galactomannan utilization in germinating legume seeds. Phytochemistry 15:43-47

McKersie BD, Senaratna T, Bowley SR, Brown DCW, Krochko JE, Bewley JD (1989) Applications of artificial seed technology in the production of hybrid alfalfa (Medicago sativa L.). In Vitro Cell Dev Biol 25:1183-1188

Meijer EGM (1989) Developmental aspects of ethylene biosynthesis during somatic embryogenesis in tissue cultures of Medicago sativa. J Exp Bot 40:479-484

Meijer EGM, Brown DCW (1988) Inhibition of somatic embryogenesis in tissue cultures of Medicago sativa by aminoethoxyvinylglycine, aminooxyacetic acid, 2,4-dinitrophenol and salicylic acid at concentrations which do not inhibit ethylene biosynthesis and growth. J Exp Bot 39:263-270

Murashige T, Skoog F (1962) A revised medium for rapid growth and bioassay with tobacco tissue cultures. Physiol Plant 15:473-497

Oboh HA, Muzquiz M, Burbano C, Cuadrado C, Pedrosa MM, Ayet G, Osagie AU (2000) Effect of soaking, cooking and germination on the oligosaccharide content of selected Nigerian legume seeds. Plant Foods Hum Nutr 55:97-110

Pescador R, Kerbauy GB, Kraus JE, Ferreira WM, Guerra MP, Figueiredo-Ribeiro C (2008) Changes in soluble carbohydrates and starch amounts during somatic and zygotic embryogenesis of Acca sellowiana (Myrtaceae). In Vitro Cell Dev Biol Plant 44:289-299

Peterbauer T, Richter A (2001) Biochemistry and physiology of raffinose family oligosaccharides and galactosyl cyclitols in seeds. Seed Sci Res 11:185-197

Sanchez-Romero C, Peran-Queada R, Barcelo-Munoz A, PliegoAlfro F (2002) Variations in storage protein and carbohydrate levels during development of avocado zygotic embryos. Plant Physiol Biochem 40:1043-1049

Schenk BU, Hildebrandt AC (1972) Medium and techniques for induction and growth of monocotyledonous and dicotyledonous plant cell culture. Can J Bot 50:199-204

Tonini PP, Purgatto E, Buckeridge MS (2010) Effects of abscisic acid, ethylene and sugars on the mobilization of storage proteins and carbohydrates in seed of the tropical tree Sesbania virgata (Leguminosae). Ann Bot 106:607-616

Wolkers WF, Tetteroo FAA, Alberda M, Hoekstra FA (1999) Changed properties of the cytoplasmic matrix associated with desiccation tolerance of dried carrot somatic embryos. An in situ Fourier transform infrared spectroscopic study. Plant Physiol 120:153-163

Zhang Y, Chen KS, Zhang SL, Wang JH (2004) Sugar metabolism and its regulation in post-harvest ripening kiwifruit. J Plant Physiol Mol Biol 30:23-26 